This item was submitted to Loughborough's Research Repository by the author.

Items in Figshare are protected by copyright, with all rights reserved, unless otherwise indicated.

\title{
Methodological nationalism and the domestic analogy: classical resources for their critique
}

PLEASE CITE THE PUBLISHED VERSION

http://dx.doi.org/10.1080/09557570903433654

PUBLISHER

Taylor and Francis / @ Centre of International Studies

VERSION

AM (Accepted Manuscript)

LICENCE

CC BY-NC-ND 4.0

\section{REPOSITORY RECORD}

Chernilo, Daniel. 2019. "Methodological Nationalism and the Domestic Analogy: Classical Resources for Their Critique". figshare. https://hdl.handle.net/2134/13290. 
This item was submitted to Loughborough's Institutional Repository (https://dspace.lboro.ac.uk/) by the author and is made available under the following Creative Commons Licence conditions.

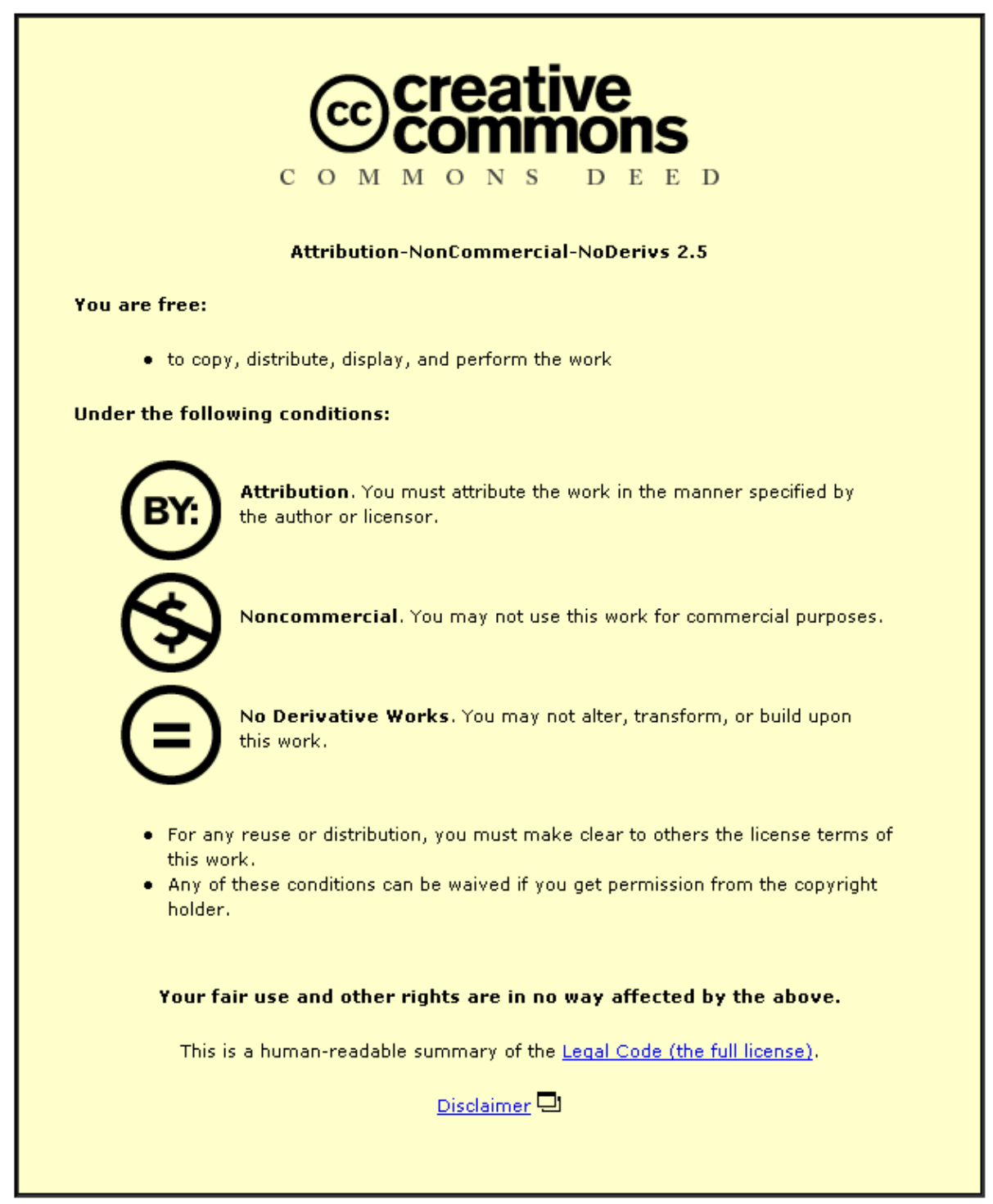

For the full text of this licence, please go to: http://creativecommons.org/licenses/by-nc-nd/2.5/ 


\title{
Methodological nationalism and the domestic analogy: Classical resources for their critique
}

(Forthcoming at the Cambridge Review of International Affairs).

\section{Daniel Chernilo*}

\begin{abstract}
The critique of methodological nationalism first arose in the early 1970s, but it was only with the rise of globalization theory that it gained salience in sociology. We have moved a long way in clarifying what we mean by, and what is wrong with, methodological nationalism and this paper argues that in International Relations the discussion of the so-called 'domestic analogy' is closely connected to the sociological debate on methodological nationalism. I shall argue that both problems point to a similar substantive direction; namely, whether the nation-state is the fundamental building block of modern society. In terms of structure, the first section of this article revisits what I consider to be the three waves of the debate on methodological nationalism in sociology. The second part connects this discussion with the debate in IR on the domestic analogy. The last section brings the two discussions together by arguing that social theory's claim to universalism is a fundamental resource to theorise current global processes beyond both methodological nationalism and the domestic analogy. But for us to unpack fully this claim to universalism, we still have to come to terms with social theory's ambivalent relationship with the tradition of natural law.
\end{abstract}

\section{Introduction: The twin critique in sociology and IR}

This paper seeks to open up a conversation between two disciplinary traditions, sociology and International Relations (IR), regarding the common problems they share when trying to understand the modern nationstate vis-à-vis international or world society. Although the debate on methodological nationalism has been more salient in sociology, it is arguably the case that its implications and consequences are, at least, equally relevant for IR.

I shall address this relationship between the two disciplines as follows. The article first revisits the debate on methodological nationalism in sociology and highlights the key aspects of each of the three waves of the discussion - in the late 1960s and early 1970s as a critique of Parsonian sociology, at the end of the last century as the rise of globalisation theory, and more recently as a reassessment of the national and global

\footnotetext{
* Associate Professor of Sociology, University Alberto Hurtado, Chile. Email: dchernil@,uahurtado.cl
} 
aspects of sociology. The second section surveys IR's debate over the domestic analogy. As sociology's coming to terms with its own methodological nationalism has revitalised the discipline's theoretical selfreflection, a similar gain may be available for IR with regard to the domestic analogy. More specifically, I shall argue that attention is paid not only to the difficulties arising out of its 'domestic' side but also to those coming out of its 'analogical' aspect. The article's third and last part offers some resources for the simultaneous critique of methodological nationalism and the domestic analogy. Surely, contemporary solutions to the problems faced by sociology and IR require novel, original and more flexible ways of studying the nation-state's unprecedented current transformations but they equally need to reengage with their own past and philosophical foundations. I should like to emphasise that current attempts at understanding the current condition of modernity, and the position of the nation-state within it, may better off by acknowledging classical social theory's claim to universalism - the truly worldwide vocation of modernity - and its natural law layout - the presupposition of the fundamental unity of the human species and ultimate equality of all individual human beings. For us to do so, however, we may still have to come to terms with these disciplines' debt to the tradition of natural law.

\section{The critique of methodological nationalism in sociology: A debate in three waves}

The first explicit wave of critiques of methodological nationalism became salient in the 1970s and its history is closer to the discipline of sociology than to any other social science - and there seem to be good reasons for that to be the case. A first underlying theme running through it was the highly popular demolition exercise of the still predominant Parsonian mainstream in sociology back then and it is difficult to overlook the rather adbominem way in which the first wave of the argument took shape. The debate could effortlessly but in retrospect also rather artificially cohere because, underneath an apparent disparity of concerns over the problems being experienced when conceptualising nations and nation-states, the common enemy was the alleged as well as real shortcomings of Parsons' systemic model. Indeed, as it happened with the misconceptions and miscarriages of the broader debate on Parsons' sociology (Alexander 1987, Gerhardt 2002), a number of prejudices and even opposite charges were already and simultaneously being pressed against him. Thus, when in an excellent essay on the question of time in sociological theory Herminio Martins (1974: 247) actually coined the notion 'methodological nationalism', he began the article by arguing that 'the demolition of functionalism is almost an initiation rite of passage into sociological adulthood or at least adolescence. If functionalism did not exist - or had not existed - it would have had to be invented'. ${ }^{1}$ Martins

\footnotetext{
${ }^{1}$ The exact quotation in which Martins (1974: 276) came up with the term 'methodological nationalism' also bears the mark of a critique of Parsons: 'In the last three decades or so the principle of immanent change has largely coincided with a general presumption - supported by a great variety of scholars in the entire spectrum
} 
was in fact referring to the way in which a number of sociologists had launched ferocious attacks on Parsonianism - and even on Parsons' himself - on all sorts of grounds: Ralf Dahrendof's (1958) critique of the alleged conservative utopianism of the Parsonian view of the social system; David Lockwood's (1992 [1963]) attempt to give functionalism a critical edge on the basis of his distinction between social and systemic integration, Gianfranco Poggi's (1965) critique of Parsons' inability to study interstate relations, Anthony Giddens' (1977) later attack on functionalism's logical and epistemological difficulties - to name only those whose charges can be directly related to the deficiencies of methodological nationalism. ${ }^{2}$

If we were now to formalise the main aspects under discussion during this first wave, we would see that the critique of methodological nationalism meant three highly related yet different charges against the social sciences' understanding of the nation-state. They were guilty of: (1) regarding the nation-state as the necessary container of modern social relations (Martins 1974); (2) conceiving of it as a natural representation of modern 'society' (Giddens 1985) and; (3) reifying the nation and thus neglecting the active role of nationalism as a modern political ideology (Smith 1983). A key feature of this early debate was that the historical record seemed to buttress a view of the modern world as increasingly organised around nation-states. In the aftermath of the decolonisation process of the 1960s, none of these writers was prepared to doubt that the nation-state was actually becoming a major determining factor in the modern word. Rather, they were concerned with the ways in which the nation-state was being conceptualised at the time; their problem was with the tendency to theorise the nation-state as though a monad which evolved and behaved autonomously and, because of that, to regard the international system of nation-states as a mere reflection of the behaviour of its individual members. In fact, a central point of these early critiques of methodological nationalism was the dissatisfaction with a certain internalist emphasis in the explanation of those social forces which contributed to the creation of individual nation-states (state bureaucratisation, national class structure), and not with the historical salience of the nation-state per se. The definition of methodological nationalism I prefer arises from these insights: the equation between the idea of society and the historical formation of the nationstate in modernity. And the critique of methodological nationalism comes about when the nation-state stops being the necessary representation of modern society on both historical and conceptual grounds.

of sociological opinion - that the "total" or "inclusive society", in effect the nation-state, be deemed to be the standard, optimal or even maximal "isolate" for sociological analysis (...) a kind of methodological nationalism (...) imposes itself in practice with national community as the terminal unit and boundary condition for the demarcation of problems and phenomena for social science' (my italics).

2 These criticisms fall, in my view, short of an adequate understanding of Parsonian sociology. And more importantly when it comes to the question of understanding the nation-state, they seem to have prevented the use of Parsons' own contributions to the very issues that got the debate on the critique of methodological nationalism going (Chernilo 2007a: 77-93). 
A second wave of scholarly critiques of methodological nationalism started at the turn of the new century. The criticisms of the previous generation on some of the conceptual shortcomings of mainstream sociology seemed to find further support via the 'empirical' assessment on the decline of the nation-state. Indeed, the re-emergence of the debate on and critiques of methodological nationalism is inextricably associated with understanding globalisation. And this is also a reason why the central tenets of this new wave are possibly more familiar as they draw heavily on the popular writings of sociology's most recent 'globalisation orthodoxy' (Albrow 1996, Bauman 1998, Beck 2000, Castells 1996, Urry 2000). All their differences notwithstanding, in relation to the critique of methodological nationalism the arguments of this group seem to cohere on the historical thesis that the nation-state was no longer the necessary representation of society in modernity. As soon as globalisation, however defined, came to announce the advent of a new epoch in or even beyond modernity, the nation-state became the first victim of this epochal change. The nation-state was the most relevant actor of previous historical constellations but its time is now definitively over. ${ }^{3}$ There is in fact a mixture of historical arguments - the rise of globalisation and fall of the nation-state - and theoretical arguments - the exhaustion of modernity and the inapplicability of universalistic concepts such as society which ends up configuring the new scenario in which the traditional ways that sociology used to comprehend the world were quickly becoming obsolete.

Despite all their exaggerations, there are two arguments to be made in favour of this more recent body of literature. Firstly, globalisation theorists made apparent the difficulties of the unreflective use of notions such as nationhood and society and, in so doing, have draw our attention to the salience of methodological nationalism in both theory and practice (Calhoun 1999, Smelser 1997). Secondly, they have encouraged, even if unwittingly, a more detailed scrutiny into whether past images of sociology effectively fall under the spell of methodological nationalism. It is then fair to say that we have moved a long way from the early days when the critique of methodological nationalism was yet another way of getting rid off Parsons. But as these writers' hypostatised the nation-state's most recent crisis for the thesis of its definitive decline, the consequence has been that the charge of methodological nationalism became, in practice, coeval with any purported study of the nation-state in its own terms. In other words, they left us with little option but claiming that the very attempt at studying the nation-state with conventional social scientific means became coeval with its effective reification and naturalisation.

${ }^{3}$ In Beck's formulation (2002: 51-2), the 'national organization as a structuring principle of societal and political action can no longer serve as a premise for the social science observer perspective. In this sense, social science can only react to the challenge of globalization adequately if it manages to overcome methodological nationalism, and if it manages to raise empirically and theoretically fundamental questions within specialized fields of research and thus elaborate the foundations of a cosmopolitan social and political science'. See Chernilo (2006) on the shortcomings of Beck's critique of methodological nationalism. 
The new millennium has however witnessed the rise of a third wave of discussion on methodological nationalism. I should like to follow Luke Martell's (2007) insight and argue that, as the rise of a third wave in globalisation studies is turning some of the previous shortcomings and exaggerations into more sober accounts of it, we witness a similar move in relation to the critiques of methodological nationalism. There are now an increasing number of writers who question the accuracy of methodological nationalism's representation of the past of sociology and in so doing they offer a new image of both sociology and the nation-state (Fine 2003, 2007, Inglis and Robertson 2008, Outhwaite 2006, Turner 1990, 2006, Chernilo 2007a). Surely, the leitmotif of this third wave is also that methodological nationalism must be rejected and transcended. Against wave one, we no longer regard the nation-state as the natural and necessary representation of society in modernity - and we also realise that there is no in-built internalist bias in sociological conceptions of development. In contradistinction to wave two, for its part, the claim on the definitive decline of the nation-state is obviously as one-sided as the one that spoke of its historical necessity, and the charge that methodological nationalism is the defining feature of the history of the sociology has been refuted. Actually, at least part of what is at stake refers to whether the accusation of social theory's immanent methodological nationalism says more about the deficiencies of those who make the claim than it tells us about the history of social theory itself. It is maintained, moreover, that the use of concepts with a universalistic intent such as 'society', has to be revisited and refined but by no means given up. It shall be my contention in the final section of this piece that the key resource we have for the task of deepening our understanding of the current situation of the nation-state in the current conjuncture lies precisely in recovering and bringing up to date the original universalistic vocation and orientation of the history of social theory. Current world society is no doubt unlike that of the early expansion of capitalism in the eighteenth centuries. But for us to reconsider continuities as much as discontinuities a soberer account of the tradition of social theory, and of the key philosophical underpinnings of its key concepts, remains a necessary step. Yet before we can take up this step let me turn to how a similar debate has unfolded in IR.

\section{Methodological nationalism in IR? Querying the 'domestic analogy'}

The connection between both debates in the two disciplines is not difficult to establish. Indeed, Martin Shaw (2000: 68) has drawn attention to the links between methodological nationalism and its IR counterpart namely, the domestic analogy:

Much social science sorted social relations (...) simply assuming the coincidence of social boundaries with state boundaries and that social action occurred primarily within, and secondarily across, these 
divisions (...) The core disciplines of the social sciences, whose intellectual traditions are reference points for each other and for other fields, were therefore domesticated - in the sense of being preoccupied not with Western and world civilizations as wholes but with the "domestic" forms of particular national societies (...this is called...) "methodological nationalism" and "territorialism". What it involved, above all, was a slippage from the general to the particular without bringing into the open the problematic abstraction involved in isolating the national case

Not too dissimilar a case, on this particular theme at least, is put forward by Justin Rosenberg (2006: 312) when he argues that IR's inability to think about 'the international' has to do with a domestic bias:

in the classical sociological tradition we find dynamic theorizations of internal change over historical time (the sequence of ancient, medieval and modern forms of society); and we find comparative theorizations of external difference across cultural space (contrasting European social structures with the Ottoman, Indian and Chinese among others). What we do not find, however, is a drawing together of these dynamic and comparative moments of analysis in order to theorize a specifically inter-societal dimension of social change (...) while Classical Social Theory provides enormous resources for enriching international theory, and for throwing any number of illuminating sidelights onto its central concerns, nowhere do we find it taking intellectual possession of those concerns themselves. Quite simply, there is no classical sociological theory of "the international"

Both authors point in the direction I am looking form as they establish the mirroring or even self-reinforcing effects of methodological nationalism and the domestic analogy. More precisely, if methodological nationalism was regarded as mainstream sociology's most important impediment to theorising global social processes, so the argument goes, the same holds true for IR's particular version of it - the domestic analogy. Interestingly, although Shaw and Rosenberg differ in a number of other important respects, the way in which they set-up this particular relationship still works within the defining terms of the second wave of the critique of methodological nationalism. ${ }^{4}$ Their arguments are built upon a premise that is now being fundamentally

\footnotetext{
${ }^{4}$ It is curious to note, for instance, how Rosenberg (2005) echoes almost by the word the kind of criticisms to classical sociology put forward by the same globalisation theorists he has so duly, and vehemently, criticised. The problem lies, in my view, in the methodological way in which he finds the whole canon of social theory at fault - 'Montesquieu, Rousseau, Smith, Condorcet, Malthus, Saint-Simon, Comte, Tocqueville, Marx, Mill, Spencer, 'Tönnies, Weber, Durkheim, Pareto and Simmel' - only to give later all the credit to a single towering figure (in his case, Leon Trotsky, Rosenberg 2006: 336-7). There is something troublingly fascinating indeed in this obsession to criticise classical social theory for having had no theory of the national (Smith 1983), the nation-state (Wimmer and Schiller 2002), the international (Rosenberg 2006), the global (Shaw 2000, Scholte 2000) or the cosmopolitan (Beck 2006).
} 
questioned in the most recent wave of critiques of methodological nationalism; namely, the extent to which its prevalence has in fact been such a defining feature of classical and twentieth-century sociology. I find it reasonable that, if a renovated interest in past sociology has produced unexpected results in relation to the nation-state, equally remarkable outcomes may arise when revisiting IR's explicit discussions on the domestic analogy.

In Hedley Bull's (1977: 46) classical formulation, the domestic analogy is 'the argument from the experience of individual men in domestic society to the experience of states, according to which states, like individuals, are capable of orderly social life only if, in Hobbes' phrase, they stand in awe of a common power'. A domestic analogy refers, then, to whether an 'international society' can be founded, and establish the sources of its own legitimacy, by analogically inferring what its central features are from those of the 'internal' organisation of 'national societies'. Although without explicitly speaking of it, Bull (1977: 140) himself seems aware of how methodological nationalism and the domestic analogy support one another:

The first function of international law has been to identify, as the supreme normative principle of the political organisation of mankind, the idea of a society of sovereign states (...) Order in the great society of mankind has been attained, during the present phase of the modern states system, through general acceptance of the principle that men and territory are divided into states, each with its own proper sphere of authority, but linked together by a common set of rules. International law, by stating and elaborating this principle and by excluding alternative principles (...) establishes this particular realm of ideas as the determining one for human thought and action in the present

It is indeed worthy of mention that Bull's interest in the domestic analogy takes place roughly at the same time as when the critique of methodological nationalism arose in sociology - since the late 1960s. But the relevance of this temporal coincidence lies at a more substantive plane. Both debates took shape in direct yet implicit relation to already popular assessments of methodological individualism's flaws in their explications of social phenomena (Lukes 1973, Macpherson 1962). Surely, the original meaning of the notion methodological nationalism mirrored that of methodological individualism as the same problems of upward conflation that were derived from the latter (its bottom-up conceptualisation of social relations) were now found in the former: a sociological conceptualisation of modernity has always been more than the sum of whatever number of national trajectories (Chernilo forthcoming). It thence follows that international relations could not be appropriately studied if conceived of exclusively as the result of interactions among individual nation-states. Needless to say, this is precisely the focus of Bull's critique of the domestic analogy and the basis of his notions of the international system and society. Neither in the 1970s nor in more recent 
discussions, however, has this connection between both kinds of methodological reductionisms been attempted (a path, I cannot, unfortunately, pursue here).

If we now turn our attention to Bull's crucial proposition that the 'international system' is best described as an 'anarchical society', it is apparent that he sought to grasp the rather paradoxical nature of the phenomenon of states' ordered relations in the absence of a single and central authority that would be willing and capable of enforcing such an order. The domestic analogy fails thus to account for the peculiar nature of 'the international' from both ends: from the anarchical side, because the lack of an international Leviathan simply cannot be described as a state of nature; and from the society side because the kind of order that is actually present in international relations expresses a communality of purpose, interests or even values among states that has normative components that go well beyond fear to an all-powerful world-state. In other words, Bull's critique of the domestic analogy depends upon a more fundamental critique of methodological nationalism because, in his view, IR's conceptual core can only be secured if the international is defined as an autonomous realm of social relations whose existence and autonomy can be credited regardless of the presence of a state. States are of course present and have a role in Bull's 'international society', but when it comes to his critique of the domestic analogy the key point is, in my view, that of the logical as well as ontological independence between state and society.

In his attempt at theorising the different sources of order that make up the notion of the international society, Bull follows Martin Wight's distinction of three traditions. In between the two extreme positions of Hobbesian realism - based on the fear to war - and Kantian universalism, based on a 'potential community of mankind', Bull (1977: 24) opts for what he terms as Grotian internationalism:

The Grotian prescription for an international conduct is that all states, in dealings with one another, are bound by the rules and institutions of the society they form. As against the view of the Hobbesians, states in the Grotian view are bound not only by rules of prudence or expediency but also by imperatives of morality and law. But as against the view of the universalists, what these imperatives enjoin is not the overthrow of the system of states and its replacement by a universal community of mankind, but rather acceptance of the requirements of coexistence and co-operation in a society of states (Bull: 1977: 27)

\footnotetext{
${ }^{5}$ I believe Bull misrepresents Kant's position as if best represented in the notion of a political community of all human beings. Even when Bull (1977: 244, 322) acknowledges that Kant's cosmopolitanism explicitly advocates for a 'league of 'republican states', he wrongly treats that league as a 'substitute goal' (Bottici 2003, Habermas 2001, Huntley 1996, Fine 2007). More on this below.
} 
The fact that Bull construed his positive argument on international society around the critique of the domestic analogy means that, as a way of thinking, its existence and relevance for the field as a whole was beyond question. Bull's theoretical framework fully rejected the domestic analogy but, equally importantly, it had to be able to establish the discipline on strong enough grounds as to avoid its eventual reintroduction implicitly or otherwise - thence the strategic importance he attributed to conceptualising the international society' as an autonomous field of social relations. It is interesting to ask how, and with independence of Bull's own intentions, this form theoretical reasoning has been later assessed as an attempt at transcending the domestic analogy.

Barry Buzan (2004: 26) has concentrated on exactly this difficult problem in his recent reassessment of the English school. On the one side, he recognises that this school's key notion of international society is not based on the crude idea of a "domestic analogy" (...) which simply scales the society within states up to the global level' (my italics). Yet on the other side, he makes the point that the case is less clear-cut than it first appears because ' $[\mathrm{t}]$ he basic idea of international society is quite simple: just as human beings as individuals live in societies which they both shape and are shaped by, so also states live in an international society which they shape and are shaped by' (Buzan 2004: 8). In his account, therefore, the three traditions we have seen Wight and Bull identify as the intellectual sources of international relations are all equally able to buttress the domestic analogy: individuals as well as nation-states may enter into ordered or even legal relations among themselves out of fear (the Hobbesian version of the analogy), shared interests (the Grotian version) or moral duty (the Kantian version). The point then is whether or not some kind of domestic analogy is in actual operation despite any particular author's explicit intentions. And in fact a major argument in Buzan's own reassessment of the English school is that the very notion that looks best equipped to conceptualise current global transformations and challenges, that of the 'world society', is little else than a 'residual category' or an 'analytical dustbin' (Buzan 2004: 28, 44). It is in the absence of a consistent notion of world society that the backdoor stays open for the reintroduction of the domestic analogy; namely 'the creation of the global equivalent of domestic politics' (Buzan 2004: 35).

I have two preliminary comments to make on these reflections for what I shall be arguing in the final section of this article. Firstly, it is true that no concept of world society is available in Bull's work. Yet Bull speaks consistently of those deeper normative commitments that underpin not only any possible conception of world society but also his actual notions of international system and international society. A 'cosmopolitan or world justice' is not readily noticeable as a social phenomenon but can nonetheless be identified as 'the common ends or values of the universal society of all mankind, whose constituent members are individual human beings' (Bull 1977: 84). Buzan (2004: 36) is right in pointing out that the idea of world society we 
require cannot simply be based upon the ontological and normative primacy of the individual. ${ }^{6}$ And below I will be taking up Bull's insight on the presence of certain underlying universalistic commitments very seriously; namely, social theory's natural law layout. In fact, similar to what happens with the notion of international society, again in the case of world society the question is whether the concept refers to a particular realm whose autonomous existence can be unequivocally established. Secondly, Buzan's (2004: 39) own framing of the question of the recurrence of natural law is revealing of the difficulties we face: '[o]ne of the curiosities here is that both the moral primacy of individuals and the assumption of universalism come out of the natural law tradition that Bull rejected, yet remained strong in his conception of international and world society'. As I suggested it in the previous section, the tradition of social theory is a rich intellectual source from which to reconstruct and then unpack the claim to universalism that is necessary for any contemporary notion of world society. But for us to do so, I shall be drawing the admittedly troubling consequence that natural law keeps coming back to haunt social theory. More positively, it is my contention that we still need to address the question of social theory's natural law heritage and we must pursue such an endeavour without presupposing that modern social theory has already succeeded in leaving natural law definitively behind.

To date, the most systematic survey available on the domestic analogy in IR seems to uphold the view that understanding its role and prevalence escapes simple definitions. Hidemi Suganami's definition of the analogy is not only different from Bull's; it also helps display some of the real difficulties it poses: '[t]he "domestic analogy" is presumptive reasoning which holds that there are certain similarities between domestic and international phenomena; that, in particular, the conditions of order within states are similar to those of order between them; and that therefore those institutions which sustain order domestically should be reproduced at the international level' (Suganami 1989: 1). In fact, part of his argument is that no real debate on the origins, role and prevalence of the domestic analogy in IR had yet taken place. Rather the opposite, 'apart from exceptional instances where a debate appears actually to have taken place (...) the idea of a "debate" is metaphorical. What can in fact be said to have existed are contending intellectual dispositions in the long line of speculations about the system of states' (Suganami 1989: 22-3). But similar to what happens in the debate on methodological nationalism that is increasingly no longer the case. The question of IR's reliance on the domestic analogy has remained at the centre of the complaints within the discipline on the chronic weaknesses of its own theoretical foundations (Bottici 2003, Buzan 2004, Rosenberg 2006, Shaw 2000, Walzer 1977). Suganami's own position goes however in a different direction from that of the reining consensus in IR: '[a]gainst the apparent intellectual legi,timacy of the belief in the defectiveness of the domestic analogy,

\footnotetext{
${ }^{6}$ In sociology, such possibility is readily available in Niklas Luhmann's notion of a world society (Luhmann 1977, Stichweh 2000). Luhmann's work has been introduced into IR by Mathias Albert and his colleagues at Bielefeld University. See, for example, Albert and Hilkermeier eds. (2004).
} 
particularly among the contemporary academic specialists of IR, there lingers the notion that perhaps some form of domestic analogy is acceptable after all (...) some degree of concession to the analogy is beneficial (Suganami 1989: 10 \& 1). If this sociologist understands the situation correctly, the challenge is that IR legitimately aspires to establish firmly the autonomy of 'the international' as a specific realm of the social, so it is bound to explicitly reject the use of the domestic analogy in whatever shape or form. The question remains, however, why has IR been unable to expunge the device entirely and keeps not only reintroducing it but also, as Suganami points out, giving ‘some degree of concession’ to it.

Although he does not really develop it, Suganami himself hints towards a different angle for the assessment of the domestic analogy. He suggests that contemporary scholars may be misreading the extent to which the seventeenth- and eighteenth-century writers who had allegedly launched the use of the domestic analogy in IR 'considered their legal reasoning as being specifically analogical when they asserted that certain principles governed the relations of sovereigns. These principles, in their view, were axiomatic and governed buman conduct universally. It was because of this axiomatic universal validity that, in their view, natural law governed international relations' (Suganami 1989: 19, my italics). Suganami's critical insight is that the debate on the domestic analogy cannot centre only on the accuracy of its domestic dimension but that its analogical element must also be questioned. A point Chiara Bottici (2003: 402) has forcefully made in her reading of Kant's cosmopolitan outlook as a critique of the domestic analogy:

Kant could never have moved from the domestic experience for saying that, since this has been successful, states should follow it and also enter a lawful condition - as Bull in his interpretation suggests. On the contrary, Kant moves from an a priori postulate of reason and then applies it to all possible cases: individual within a nation, states in their relationship with one another, and finally, individual and states as far as human beings are regarded as citizens of a universal state of mankind

Without entering here into a discussion on the problems of a priori reasoning, it is sufficient for my argument to note that, because an analogy is a form of thinking that uses empirical evidence that is held valid within a particular realm and extrapolates it onto a different one, no domestic analogy is found in Kant. Rather the opposite, Kant's preferred form of conceptualization is based on the systematic application of fundamental principles that hold valid to all realms of human life. In relation to IR's difficulty with the domestic analogy, the question of the ontological autonomy of the international vis-à-vis the national and the global remains of course a critical issue, but one which is now suspended until we answer the prior question of whether the similarities and differences between these realms can be thought of analogically. What at first seemed to appear as an analogy has in fact demonstrated otherwise; there is a deeper layer of philosophical foundations 
that points towards an understanding of the social as such. It is only within a general theory of social that it makes sense to distinguish among different and autonomous realms - the national, the international, the regional and the global (but also some others). The domestic analogy creates so many complications for IR not because of the substantive differences between the domestic and the international (as they actually exist) but because, methodologically speaking, no analogy can really be deployed when looking at what takes place at the domestic level with a view to understanding the international. What we really need to do is to grasp the deep-seated philosophical presuppositions that underpin our social scientific conceptualisations of what constitutes modern social life in general; it is only, and insofar as, we are able to say something meaningful about what is it that constitutes social relations that the differentiation between the local, national, international and global levels begins to make sense. IR's apparent vicious circle of explicit rejection and implicit reintroduction of the domestic analogy will only be broken when the domestic analogy is pulled apart simultaneously from both ends - the domestic and the analogical. For the broader aim of this article, the argument I am putting forward is that a claim to universalism, both analytic and normative, is intrinsic to the very project of trying to conceptualise modern social life in all its scales.

Let me bring this section to a close by recalling that the domestic analogy seems to be the particular name that the broader debate on methodological nationalism in social theory has adopted in IR. As a substantive field of enquiry, both refer to understanding the main features of the nation-state vis-à-vis the global constitution of modernity. The reductionist understanding of both sociology and IR on the basis of their respective, indeed mutually reinforcing, dependence on iternalist assumptions and biases can and must be refuted; neither methodological nationalism nor the domestic analogy lie at the centre of these disciplines. Their critique requires thus not only that they are explicitly rejected but to avoid that they are implicitly reintroduced. We need to grasp those universalistically oriented conceptions of the social that at all different scales underpin modern social theory so that its original claim to universalism can be recovered and then renovated. For us to do so, however, the idea of social theory's natural law layout will have to be reckoned with.

\section{A claim to universalism: Social theory's natural law layout}

The study of the connections between natural law and the rise of social theory is far from original (Fine 2002, Habermas 1971, Koselleck 1988, Löwith 1964, Strauss 1974, Toulmin 1990, Troeltsch 1925, Voegelin 2000). It is nonetheless fair to argue that this theme does not figure prominently in sociological accounts on the rise of social theory. Natural law has been conspicuously absent from most of the best-known accounts of the rise of sociology during the twentieth century (Aron 1965, Giddens 1971, Hawthorn 1987, Seidman 1983). And as our brief recount in the previous section makes apparent, IR theorists do not seem to find it fashionable to 
refer to natural law nowadays. But to the extent that early modern natural law theorists such as Suárez, Grotius and Puffendorf were explicitly concerned with the foundation and functioning of the international system (García y García 1997, Haakonssen 1996, Hochstrasser 2000, Tuck 1981), IR may not be particularly unsuited to raise this connection. To put it as clearly as possible, my argument to link universalism and natural law refers to the following four planes: (1) its interest in the possibility of supra-historical normative standards; (2) its egalitarianism (the view that all individual human beings belong to the same species); (3) its critical role in setting rational standards against which actually existing social arrangements can be assessed, and; (4) its notion of a stratified ontology so that the (social) world is understood as composed of different and autonomous realms. ${ }^{7}$

I am aware of the fact that to argue for the salience of natural law presuppositions for the current functioning of social theory is far from unproblematic. I should therefore like to make explicit that it is not my intention to revive natural law for its own sake or indeed to hold that in natural law we are going to find the master key with which to solve all of social theory's present problems. But contemporary calls for reinventing the wheel have proved damaging for social theory's historical, conceptual and normative reflection. The reassessment of its debt to natural law may serve, at the very least, the noble purpose of making apparent social theory's deepseated philosophical structure. But more consequential for my argument here, it will help us move beyond both methodological nationalism and the domestic analogy.

Interestingly, and in order to make my argument more plausible in terms of IR, we can again resort to Hedley Bull for what I consider to be a sensible attitude to addressing the role of natural law in social theory without wanting to pursue a natural-law agenda for its own sake:

I don't wish to embrace the position of exponents of the doctrine of natural law that (...) primary or universal goals of social life are mandatory for all men, or that the binding force of rules of conduct upholding them is self-evident to all men. It is true that the position I have adopted here can be said

\footnotetext{
${ }^{7}$ The natural law tradition is of course highly heterogeneous and any attempt to produce a general definition of it is likely to cause controversy. Apart from its standard connections with Stoicism and Roman Law (d'Entrèves 1970), natural law has been demonstrated compatible with several ancient religious cosmologies (Voegelin 1962), Catholic conservatism (Rommen 1998, Gierke 1927), liberalism (Schneewind 1998), different kinds of republicanism (Arendt 1958, Benhabib 2004, Bohman 2004, Skinner 1998), postmodern legal studies (Douzinas 2000) and even Marxism (Bloch 1996). My thesis that a claim to universalism serves to characterise it as a whole may seem to leave out early modern natural-law writers that were of critical importance for the establishment of modern conceptions of state sovereignty (i.e. Hobbes and Locke). Against this possible objection, I believe that insofar as they were concerned with setting up first principles that would serve to establish any form of modern social order, a claim to universalism does remain in place - although admittedly its universalistic threshold has been lowered down.
} 
to have been part of the "empirical equivalent" of the natural-law theory, which sought to deal with elementary or primary conditions of social existence in the idiom of a different era. Indeed, the natural law tradition remains one of the richest sources of theoretical insight into the matters dealt with in the present study. But it is not part of my intention to revive the central tenets of natural-law thinking itself (Bull: 1977: 6-7)

Bull seeks neither to endorse nor to reinforce natural law yet he finds important to realise that we cannot simply ignore it. I would like to take up his insight that there is an intellectual obligation in recognising that natural law plays a much bigger role than usually acknowledged, and we may want it to play, within the intellectual tradition of the social sciences. My difference with Bull lies in that rather than describing my position as an 'empirical equivalent' of natural law, I am interested in understanding its role as a template or actually a layout without which social scientific concepts and methods can hardly operate. In fact, in a paragraph that R. J. Vincent (1988: 198) has described as 'tantalising' in the context of Bull's oeuvre, we read: 'it has been maintained that world order, or order within the great society of all mankind, is not only wider than international order or order among states, but also more fundamental and primordial than it, and morally prior to it' (Bull 1977: 319, my italics). That a statement such as this one comes at the very end of The Anarchical Society shows that Bull seems to have stumbled upon a result that goes beyond his own preferred structural diagnostic of the international system as much as beyond the normative consequences that are immediately apparent from it. Bull becomes a cosmopolitan in spite of himself, as it were, because he realises the extent to which international relations cannot be thought of without universalistic presuppositions that belong to the tradition of natural law. ${ }^{8}$

Social theory's long-term research agenda - the empirical account of the rise and main features of modern social life - depends upon a claim to universalism whose contentious origins lie in the tradition of natural law (Chernilo 2007a). Yet the same critical trends that may be seen as challenging natural law's belief in the unity of the human species - historical change, socio-cultural variation and normative disagreement - have themselves been referred to as the fundamental experiences that gave rise to natural law. Indeed, it is this relationship between unity and diversity, universality and particularity in the origins of the natural law tradition that I would like to unfold briefly here. Writing in the 1930s, this is how Catholic lawyer Heinrich Rommen (1998: 4) traces the emergence of natural law in separation from divine law:

\footnotetext{
${ }^{8}$ In fact, in his later work Bull (1984) increasingly moved towards the more normative wing of the English School. Thanks to George Lawson for having raised this point to my attention.
} 
The idea of a natural law can emerge only when men come to perceive that not all law is unalterable and unchanging divine law. It can emerge only when critical reason, looking back over history, notes the profound changes that have occurred in the realm of law and mores and becomes aware of the diversity of the legal and moral institutions of its own people in the course of its history; and when, furthermore, gazing beyond the confines of its own city-state or tribe, it notices the dissimilarity of the institutions of neighboring peoples. When, therefore, human reason wonderingly verifies this diversity, it first arrives at the distinction between divine and human law

From this fundamentally religious formulation, we can see that traditional natural law entered modernity and thus social theory - via the secularisation of some of its presuppositions. The thesis of the rise of modernity as a process of secularisation, the way in which transcendental references to a divinely organised cosmos are transformed into an immanent conception of history understood exclusively in terms of human progress, was masterfully taken up by Karl Löwith in the late 1940s:

A universal history directed toward one single end and unifying, at least potentially, the whole course of events was not created by Voltaire but by Jewish messianism and Christian eschatology, on the basis of an exclusive monotheism. Once this belief had been adopted generally and had prevailed for centuries, man could discard the doctrine of providence, along with that of creation, judgement, and salvation, but he would not return to such views as had satisfied the ancients. Man will seek to replace providence, but within the established horizon, by secularizing the Christian hope of salvation into an indefinite hope of improvement and faith in God's providence into the belief in man's capacity to provide for his own earthly happiness (Löwith: 1964: 111)

Following Löwith, part of my argument here is that classical social theory took up a challenge that is similar to the one which is described as central to natural law. With modernity, the idea of humanity can only be meaningfully comprehended if treated as a single subject and this is a presupposition shared by modern social theory and the natural law tradition alike. Yet I should not wish to endorse another aspect of Löwith's thesis; namely, that social theory has no cognitive autonomy whatsoever and to that extent it effectively dissolves into yet another form of natural law. ${ }^{9}$ Writing in the early 1950s and a friend of Löwith's, Leo Strauss was precisely of the idea that natural law had to be approached with full independence of religion. Indeed, that is precisely the reason why he prefers the notion of natural right rather than natural law to frame his intellectual

\footnotetext{
${ }^{9}$ The so-called secularisation debate was initiated by Hans Blumenberg's (1983) response to Löwith, which centred on the question of the legitimacy of modernity's claim to fully secular self-assertion. See Barash (1998) and Wallace (1981) for further discussion.
} 
enquiry there: 'knowledge of the indefinitely large variety of notions of right and wrong is so far from being incompatible with the idea of natural right that it is the essential condition of the emergence of the idea: realization of the variety of notions of right is the incentive for the quest of natural right' (Strauss 1974: 10). He goes further back than to Christianity and seeks the origins of the natural right tradition in Socrates and Plato. It is there, argues Strauss (1974: 89), that 'the discovery of nature is identical with the actualization of a human possibility which, at least according to its own interpretation, is trans-historical, trans-social, transmoral and trans-religious'.

Strauss is interested in comparing the natural right theories of classical Greece with those that gave rise to modern thinking in the works of Machiavelli and Hobbes. The central feature both traditions share is that they are similarly based upon anthropological (immanent) rather than religious (transcendent) premises. The answer to the questions of what constitutes the humanity of human beings and how to best pursue life in common are based upon the thesis that '[a]ll natural right doctrines claim that the fundamentals of justice are, in principle, accessible to man as man' (Strauss 1974: 28). But Strauss also highlights the differences between Greek and modern natural right doctrines; the most salient among them being that only the moderns have a conception of fully 'egalitarian natural right (...in which...) all men are by nature free and equal. Natural freedom and natural equality are inseparable from each other' (Straus 1974: 118, my italics). ${ }^{10}$

Social theory has surely sought to overcome all different versions of natural law theory but, in so doing, it tends to presuppose and fall back to some form of it. In speaking of modern social theory's natural law layout, therefore, I refer to a deep-seated philosophical commitment that can be found in operation regardless of whether it is explicitly recognised or desired. To the extent that its rise coincides with that of modernity's global expansion and impact, social theory has its own a vested interest in grasping what is it that now constitutes, to paraphrase Bull's formulation, our 'great society of mankind': what is it that makes modern social relations social, why do they keep expanding all across the world, how can such novel forms of social relations be studied, are we able to determine unequivocally the best possible way of organising our life in common. Even if it would be wholly inappropriate to see sociology or IR as the social scientific incarnation of a natural-law doctrine that had developed mostly at a philosophical level, I believe it necessary to spell out some of their natural law presuppositions so that we can critically reflect upon them. It is my contention, therefore, that modern social theory emerging in the nineteenth century is built upon this kind of natural law layout. The social sciences work under the normative and analytical presuppositions of the fundamental unity of the

${ }^{10}$ As he arrives at this formulation, Strauss (1974: 181-2) himself makes the point that modern natural right thinking is closely associated to liberalism. But it is his own account of natural right's historical evolution that saves Strauss from Robert Nisbet's (1967) mistake of conflating natural law as such with the modern egalitarianism of the Enlightenment. 
buman species and of the equality of all individual buman beings. This natural law layout underpins - more often implicitly than not - the work of the most salient social theorists not only in their normative standpoints but also in their concepts and methods (Chernilo 2009a). It not only runs deeper than methodological nationalism and the domestic analogy but can also play an important role in their critique.

Furthermore, this narration I have so sketchily introduced may lend support to the view that modern social theory had to construe a subtler and more differentiated conception of universalism in order to explain the dramatically enhanced experienced of cultural particularisms and ethical discrepancies in modernity. The very idea of the social upon which our disciplines have been historically established presupposes the unity of the human species and the equality of individual human beings. All forms of gender, ethnic, cultural, national and religious differences are theorised as something internal to the substantive unity of humanity; the very existence of such differences is taken as the expression of the ultimate equality of all human beings. Everything can be different among human groupings - mores, tastes, norms and values - but the idea that something social emerges out of the interaction about human beings ultimately underpins all these differences. Social theory explicitly sought to leave natural law behind but, in practice, still requires it because its key concepts presuppose an argument about humanity's ultimate unity. The tradition of social theory requires a claim to universalism that operates at three formally independent, yet mutually reinforcing, planes: (1) the normative idea of a single modern society that encompasses the whole of globe and all human beings; (2) the conceptual definition of what is the social element in modern social relations and; (3) the methodological justification of how to generate adequate empirical knowledge (Chernilo 2007b).

As it is obviously impossible even begin to substantiate these propositions in full, let me finalise by abusing of Bull's work to illustrate further my key claims. A crucial element in his reflections on the nature of order in the international society is the way in which, ever since its origins within a natural law framework in the seventeenth century, international law has tried to establish itself beyond natural law, only for later writers to be confronted with it in a renovated fashion. Indeed, the very coinage of the term 'international law' was expected to express the final decline of natural law and the advent of a true positive science of international relations:

In identifying the sources of the rules by which states are bound, theorists of international society in the eighteenth and nineteenth centuries turned away from natural law and towards positive international law (...) When they came to formulate the rules of coexistence, theorists of this period were able to free themselves of the universalist or solidarist assumptions inherited from mediaeval times, and to take account of the unique characteristics of the anarchical society. The term "law of 
nations", droit des gens, Volkrrecht, not only drove out the term "law of nature", with which it had previously always been coupled; it came quite clearly to mean not law common to all nations, but law between nations. The transition was completed when the term "law of nations" itself gave way to "international law', the term coined by Bentham in 1789 in his Introduction to the principles of Morals and Legislation (Bull 1977: 35-6)

The plot is fascinating. On one side, Bull acknowledges how short-lived this apparently definitive rejection of natural law became - both explicitly and implicitly: '[i]t was characteristic of the natural law theorists that they in no case wholly liberated themselves from the ambiguities of the Roman term ius gentium, as between its modern meaning of "international law" or law between states and nations, and its original meaning of a law common to all nations' (Bull 1977: 30). In other words, the more international law sought to go beyond and overcome its natural law origins, the more it was drawn back to it. On the other side, however, "[i]deas of international society in the twentieth century may be said to be closer to those that were entertained in the early centuries of the states system than to those that prevailed in the eighteenth and nineteenth centuries' (Bull 1977: 38). Rather than a linear path towards either the fulfilment or the definitive decline of natural law, Bull's own analysis point towards the permanent Aufhebung - the suspension and carrying forward - of natural law presuppositions.

Problematic as any attempt at connecting social theory with natural law surely is, it is my contention that we can break away from conservative or highly metaphysical versions of natural law only if we are willing to deal with them head on. Natural law will not simply vanish into thin air, but its claim to universalism can surely be refined, made more reflective and become subject to critical reflection. The more we recognise this natural law layout and start making explicit that which until now remained implicit, the more we can refine our critiques of both methodological nationalism and the domestic analogy. Precarious and temporary as they will surely remain, the solutions we require depend upon subtler references to social theory's claim to universalism.

\section{Conclusions}

Methodological nationalism and the domestic analogy are real, but they are neither the most fundamental presupposition of their respective disciplines nor the key feature of social theory as an intellectual tradition. If, as I am arguing here, social theory's critical core lies rather in a claim to universalism whose natural law layout still needs to be fully understood, what we need to do in order to overcome methodological nationalism and the domestic analogy is to uncover what lies underneath them. The kind of critique I am suggesting requires 
that we are able to see through methodological nationalism and the domestic analogy by reconstructing and reassessing the natural law elements that remain within social theory.

The openness to understand what is changing in the current conjuncture requires that we also acknowledge what remains. Sociology and IR's attempts to conceptualise the global vis-à-vis the national and the international belong fully in the tradition of classical social theory's claim to universalism. In contradistinction to the case we often get in contemporary writings in either discipline, my argument is that no major theoretical overhaul is in sight. The notions of the global, world society or cosmopolitanism we find in classical social theory are surely full of difficulties, and corrections are needed to make profitable use of them in the present. But the critical point is that, rather than more or less spectacular declarations of obsolescence, the resources we need are to be found deeper and within the canon of social theory itself. Deeper, because its natural law layout is not immediately apparent and needs to be brought out; within, because it is about refining one of social theory's most enduring feature, its universalistic legacy. I am not arguing here that all we need to do to move beyond methodological nationalism is to spend some time reading old books and draw on early modern metaphysics. But neither will we move forward by simplifying our historical and philosophical understanding of the social sciences' key concepts.

Sociology and IR have much to learn from one another - not least in relation to how to come to terms with their own common history. IR has experienced chronic problems in arriving at a notion of the international that cuts ice, its key contribution to researching into the global and cosmopolitan aspects of the world society seems to lie, even if in spite of itself, in its slightly clearer awareness of its debt to natural law. This potential may begin to be realised, however, if it stops being afraid or ashamed of natural law and starts treating the tradition for what it is. Sociology, for its part, must revisit the way in which it narrates its own past as if there was no pending debt to natural law. Yet its long-lasting preoccupation with modernity's universalistic vocation, as well as its concern with an ever more abstract definition of the social, remain sociology's irreplaceable contribution to understanding what modern social life is about. The discussions in both disciplines show that there is no need to see either intellectual tradition as fully defective. Rather, we may be better advised if, in reconstructing them, we let difficulties emerge and tentative solutions unfold. What we require is a revision of our understanding of the foundational period of the social sciences so that we stop imposing a view of the centrality and necessity of the nation-state that is simply not valid.

17 April 2009. 


\section{Acknowledgment}

This article is part of a wider research project into the relationship between social theory and natural law that receives financial support by the Chilean Council for Science and Technology (Grant 1080213).

My gratitude to José Maurício Domingues and Frederic Vandenberghe for inviting me to present this paper at IUPERJ's Theory Forum in Rio de Janeiro in December 2008. My thanks also to William Outhwaite for suggesting my name to the editors of this forum, George Lawson and Robbie Shilliam, whose extraordinary editorial work went well beyond the call of duty. As ever, I am deeply indebted to Robert Fine for comments to an early version of this article - and beyond

\section{References}

Albert, M. and L. Hilkermeier (eds.) (2004) Observing International Relations: Niklas Luhmann and World Politics, London: Routledge.

Albrow, M. (1996) The Global Age, Cambridge: Polity Press.

Alexander, J. (1987) Sociological theory since 1945, London: Hutchinson.

Arendt, H. (1958) The origins of totalitarianism, New York: Meridian Books.

Aron, R. (1965) Main Currents in Sociological Thought, 2 Vols., London: Weidenfeld and Nicolson.

Barash, J. (1998) 'The sense of history: On the political implications of Karl Löwith's concept of secularization', History \& Theory 37 (1): 69-75.

Bauman, Z. (1998) Globalization, Cambridge: Polity Press.

Beck, U. (2000) What is globalization?, Cambridge: Polity Press.

Beck, U. (2002) 'The terrorist threat. World risk society revisited', Theory, Culture \&o Society 19 (4): 39-55.

Beck, U. (2006) Cosmopolitan Vision, Cambridge: Polity Press.

Benhabib, S. (2004) 'Reclaiming universalism: Negotiating republican self-determination and cosmopolitan norms', The Tanner Lectures on Human Values, Last access 20 August 2007 (available at: http://www.tannerlectures.utah.edu/lectures/volume25/benhabib_2005.pdf). 
Bloch, E. (1996) [1961] Natural Law and Human Dignity, Massachusetts: MIT Press.

Blumenberg, H. (1983) [1966] The legitimacy of the modern age, Massachusetts, MIT Press.

Bohman, J. (2004) 'Republican cosmopolitanism', Journal of Political Philosophy 12 (3): 336-52.

Bottici, C. (2003) 'The domestic analogy and the Kantian project of Perpetual Peace', The Journal of Political Philosophy 11 (4): 392-410.

Bull, H. (1977) The Anarchical Society, New York: Columbia University Press.

Bull, H. (1984) Justice in International Relations, Ontario: University of Waterloo Press.

Buzan, B. (2004) From international to world society? Cambridge: Cambridge University Press.

Calhoun, C. (1999) 'Nationalism, political community and the representation of society. Or, why feeling is not a substitute for public space', European Journal of Social Theory 2 (2): 217-31.

Castells, M. (1996) The rise of the network society, Oxford: Blackwell.

Chernilo, D. (2006) 'Social theory's methodological nationalism: myth and reality', European Journal of Social Theory 9 (1): 5-22.

Chernilo, D. (2007a) A social theory of the nation-state: The political forms of modernity beyond methodological nationalism, London: Routledge.

Chernilo, D. (2007b) 'A quest for universalism: Re-assessing the nature of classical social theory's cosmopolitanism', European Journal of Social Theory 10 (1): 17-35.

Chernilo, D. (2009) 'Cosmopolitanism and social theory', in Turner, B. S. (ed.), The New Blackwell Companion to Social Theory, Oxford: Blackwell.

Chernilo, D. (forthcoming) 'Methodological Nationalism: Theory and History', Thesis Eleven. 
d'Entrèves, A. (1970) Natural Law, London: Hutchinson

Dahrendorf, R. (1958) 'Out of utopia: Towards a reorientation of sociological analysis', American Journal of Sociology 64 (2): 115-27.

Douzinas, C. (2000) The End of Human Rights, Oxford: Hart.

Fine, R. (2002) [1984] Democracy and the rule of law, New Jersey: The Balckburn Press.

Fine, R. (2003) 'Taking the 'ism' out of cosmopolitanism: an essay in reconstruction', European Journal of Social Theory 6 (4): 451-70.

Fine, R. (2007) Cosmopolitanism, London: Routledge.

García y García, A. (1997) 'The Spanish School of the Sixteenth and Seventeenth Centuries: A precursor of the Theory of Human Rights', Ratio Juris 10(1): 25-35.

Gerhardt, U. (2002) Talcott Parsons. An intellectual biography, Cambridge: Cambridge University Press.

Giddens, A. (1971) Capitalism and Modern Social Theory, Cambridge: Cambridge University Press.

Giddens, A. (1977) 'Functionalism: apres la lutte' in Giddens, A. Studies in social and political theory, London: Hutchinson

Giddens, A. (1985) The Nation-State and Violence, Cambridge: Polity Press.

Gierke, O. (1927) Political Theories of the Middle Ages, Cambridge University Press.

Haakonssen, K. (1996) Natural Law and Moral Philosophy, Cambridge: Cambridge University Press.

Habermas, J. (1971) Theorie und Praxis, Frankfurt: Surkhamp.

Habermas, J. (2001) The postnational constellation, Cambridge: Polity Press. 
Hawthorn, G. (1987) Enlightenment and Despair. A History of Social Theory, Cambridge: Cambridge University Press.

Hochstrasser, T. (2000) Natural law theories in the early enlightenment, Cambridge: Cambridge University Press.

Huntley, W. (1996) 'Kant's Third Image: Systemic Sources of the Liberal Peace', International Studies Quarterly 40 (1): $45-76$.

Inglis, D. and Robertson, R. (2008) 'The Elementary Forms of Globlality: Durkheim and the Emergence and Nature of Global Life', Journal of Classical Sociology 8 (1): 5-25.

Koselleck, R. (1988) [1959] Critique and Crisis. Enlightenment and the Pathogenesis of Modern Society, Boston: MIT Press.

Lockwood, D. 1992 [1963] 'Social integration and system integration', in Lockwood, D. Solidarity and Schism. The problem of disorder in Durkheimian and Marxist Sociology, Oxford: Clarendon Press.

Löwith, K. (1964) [1949] Meaning in History, Chicago: The University of Chicago Press.

Luhmann, N. (1977) 'Generalized media and the problem of contingency', in Loubser, J. Baum, R. Effrat A. and Lidz, V. (eds) Explorations in the general theory In social science. Essays in honor of Talcott Parsons, New York: The Free Press.

Lukes, S. (1973) Individualism, Oxford: Basil Blackwell.

Macpherson, C. B. (1962) The political theory of possessive individualism, Oxford: Oxford University Press.

Martell, L. (2007) 'The third wave in globalization theory', International Studies Review 9: 173-96.

Martins, H. (1974) 'Time and theory in sociology', in Rex, J. (ed.) Approaches to sociology, London: Routledge and Kegan Paul.

Nisbet, R. (1967) The Sociological Tradition, London: Heinemann. 
Outhwaite, W. (2006) The future of society, Oxford: Blackwell.

Poggi, G. (1965) 'A main theme of contemporary sociological analysis: Its achievements and limitations', British Journal of Sociology 16 (4): 283-94.

Rommen, H. (1998) [1936] The Natural Law: A Study in Legal and Social History and Pbilosophy, Indianapolis: The Liberty Fund.

Rosenberg, J. (2005) 'Globalization theory: A post mortem’, International Politics 42: 2-74.

Rosenberg, J. (2006) 'Why is there no international historical sociology?', European Journal of International Relations 12 (3): 307-40.

Scholte, J. (2000) Globalization. A critical introduction, London: Palgrave

Scheewind, J. B. (1998) The Invention of Autonomy. A History of Modern Moral Philosophy, Cambridge: Cambridge University Press.

Seidman, S. (1983) Liberalism and the Origins of European Social Theory, Oxford: Basil Blackwell.

Shaw, M. (2000) Theory of the Global State, Cambridge: Cambridge University Press.

Skinner, Q. (1998) Liberty before Liberalism, Cambridge: Cambridge University Press.

Smelser, N. (1997) Problematics of sociology, Berkley: University of California Press.

Smith, A. D. (1983) 'Nationalism and classical social theory', British Journal of Sociology 34 (1): 19-38.

Stichweh, R. (2000) Die Weltgesellschaft, Frankfurt, Suhrkamp.

Strauss, L. (1974) [1950] Natural Right and History, Chicago: The University of Chicago Press.

Suganami, H. (1989) The domestic analogy and world order proposals, Cambridge: Cambridge University Press. 
Toulmin, S. (1990) Cosmopolis. The bidden agenda of modernity, Chicago: The University of Chicago Press.

Troeltsch, E. (1958) 'The Ideas of Natural Law and Humanity', in Gierke, O. Natural Law and the Theory of Society: 1500 to 1800, Cambridge: Cambridge University Press.

Tuck, R. (1981) Natural Rights Theories: Their Origin and Development, Cambridge: Cambridge University Press.

Turner, B. (1990) 'The two faces of sociology: Global or national?', in Featherstone, M. (ed.) Global culture. Nationalism, globalisation and modernity, London: Sage.

Turner, B. (2006) 'Classical sociology and cosmopolitanism: A critical defence of the social', British Journal of Sociology 57 (1): 133-55.

Urry, J. (2000) Sociology beyond societies, London: Routledge.

Vincent, (1988) 'Hedley Bull and order in international politics', Millenium 17: 195-213.

Voegelin, E. (1962) 'World-empire and the unity of mankind', International Affairs 38 (2): 170-88.

Voegelin, E (2000) [1952] 'The new science of politics', in Henningsen, M. (ed.) The Collected Works of Eric Voegelin Vol. 5, Columbia: University of Missouri Press.

Wallace, R. (1981) 'Progress, Secularization and Modernity: The Löwith-Blumenberg Debate', New German Critique 22 Winter: 63- 80.

Walzer, M. (1977) Just and unjust wars. A moral argument with historical illustrations, USA: Basic Books.

Wimmer, A. and Schiller, N. (2002) 'Methodological nationalism and beyond: nation-state building, migration and the social sciences', Global Networks 2 (4): 301-34. 